\title{
Qualification requirements for entry-level IT positions and IS curriculum: A literature review
}

\author{
Thomas Ngo-Ye, Alabama State University,tngoye@alasu.edu \\ Jae Choi, Pittsburg State University,jchoi@pittstate.edu
}

\begin{abstract}
Information Technology (IT) is a dynamic field with constant emerging innovations. Demands for IT talents are growing as IT becomes ubiquitously present in all aspects of work and life. Information Systems (IS) faculty have the responsibility to prepare IS students for entry-level IT positions. Therefore, faculty need to understand what skills are required by employers, which is critical for keeping IS curriculum relevant to the current IT job market. We conduct an extensive literature review on the skills needed for entry-level IT positions, and relevant IS curriculum issues. We discover several salient themes and classify them into the following categories: Historic and big-picture overview, Skillscurriculum gap, IT specializations, Various skills, Job offer and employer characteristics, and Challenge of work-life-education balance for students. This research contributes to IS education field by summarizing the extant research on skills demanded by the industry. This study can assist faculty to improve, and redesign IS curriculum to be more relevant. This paper also helps IS students comprehend the vast scope and diverseness of the IT field, the historical trends, and the current skills in high demand.
\end{abstract}

Keywords: qualification requirements, entry-level IT positions, IS curriculum, literature review

\section{Introduction}

In the past few decades, Information Technology (IT) was one critical driver of productivity improvement and economic growth. Demands for qualified IT workers are high and continue to go up. According to the Bureau of Labor Statistics' economic and employment projections, Information Security Analysts is one of the fastest-growing occupations in the U.S. from 2012 to 2022, with an expected growth of 27,400 new openings or $36.5 \%$ growth rate (Source: http://www.bls.gov/news.release/ecopro.t04.htm). Software Developers are among the occupations with the most projected job growth in the U.S. between 2012 and 2022, with an expected growth of 139,900 new openings or a 22.8\% growth rate (Source: http://www.bls.gov/news.release/ecopro.t05.htm). Accompanying such positive IT-related job growth, companies are facing the IT skills shortage problem. IT skills shortfall in .NET, Java, and C++ may severely restrict future U.S. economic growth (Bernstein, 2013). Unable to find qualified programmers in Georgia, Home Depot hires 65 percent of its programmers from out of state, leading to higher relocation costs and increased operating cost of running satellite offices around the nation (Bluestein \& Davis, 2014). One suggested solution to meet the increasing demand for IT talent is to encourage more American students to take on computer science careers (Bernstein, 2013). For example, Home Depot planned to work with Gwinnett Technical College to train more local programmers to address the IT skills gap issue (Bluestein \& Davis, 2014).

For students majoring in Information Systems (IS) or IT, a very practical question is what critical skills they need to possess to find a professional IT job. By mining CareerBuilder's vast employment database, 


\section{Issues in Information Systems}

Volume 22, Issue 3, pp. 39-51, 2021

ten most promising occupations regarding under-supply qualified applicants relative to the number of positions were identified (Craver \& DeSenne, 2011). Four of them are related to IS: Mail Marketer, Network Security Engineer, Social Media Manager, and Software Engineer for Mobile Applications (Craver \& DeSenne, 2011). According to an IBM study released in late 2012, the most demanded IT skills are analytics, social networking, cloud computing, and mobile computing (Bernstein, 2013). Another area in demand is security skills. Finding security experts with communication and leadership skills is particularly challenging to global companies (Bernstein, 2013).

The articles published in the popular media or professional trade journals often highlight the specific IT occupations in demand and feature corresponding tangible technical skills. However, they rarely mention the importance of non-technical skills or qualifications such as communication, personal traits, or functional business knowledge. In this paper, we survey the academic literature on the required critical skills for entrylevel IT positions. We also examine articles that discuss IS curriculum issues, which are often closely related to skills demanded by the IT job market. We classify the extant empirical researches and identify several common themes.

Moreover, we recognize a few relatively under-researched areas. This study is considered as a first step in the direction of exploring our newly raised issues. We hope this research adds to the existing body of knowledge on critical IT skills. Moreover, we believe that this work is beneficial to IS faculty by highlighting the required skills that can be useful for IS curriculum redesign and improvement. This study will also benefit IS students by informing them about the expected skills for entry-level IT positions in the real world.

\section{Literature review}

\section{Historical and big-picture overview}

\section{Historical perspective of IS job market and IS curriculum}

In a longitudinal study of IS job market from the late 1970s to early 2010s, the authors discovered that the IT fields are becoming more diverse and broader in scope (Harris, Greer, Morris, \& Clark, 2012). In addition to providing the historical overview of the longitudinal trends, the researchers also identified the skills required in the current job market and a growing number of sub-specialties within the IT area. In another investigation of the nature of changes in skills over fifty years, the authors categorized the skills into these broad areas: software development, web development, database, operating systems and telecommunications, strategic organizational development, interpersonal and team skills, project management, and information and security assurance (Longenecker, Feinstein, \& Clark, 2013). While the IS curriculum has been significantly adapted over the past five decades, many core skills are recurring and partially define the IS discipline. On the other hand, smartphone-based computing and cybersecurity are rising to the level of extreme importance in IS curriculum (Longenecker, Feinstein, \& Clark, 2013).

\section{Career paths of IS graduates}

In an empirical study of career success and mobility patterns of 500 individuals who worked in the IT workforce, the authors found that the careers of the IT workforce are more diverse than the traditional conception of two paths of technical versus managerial (Joseph, Boh, Ang, \& Slaughter, 2012). Instead, there are three distinct paths: IT careers, professional labor market (PLM) careers, and secondary labor market (SLM) careers, where career success measured as average pay is similar for individuals in IT and PLM careers. However, individuals in SLM received the lowest pay. 


\section{Issues in Information Systems}

Volume 22, Issue 3, pp. 39-51, 2021

\section{Evolving nature of IT}

IT is recognized as an evolving field with new technology constantly emerging (Medlin, Schneberger, \& Hunsinger, 2007; Trauth, Farwell, \& Lee, 1993; Ven \& Chuang, 2008). Therefore, continuous reevaluation of the industry expectation of critical skills possessed by IS students and academic IS curriculum has long been an important research topic (Aasheim, Li, \& Williams, 2009; Aasheim, Williams, \& Butler, 2009; Downey, McMurtrey, \& Zeltmann, 2008; Eom \& Lim, 2012; Gallagher, Kaiser, Simon, Beath, \& Goles, 2010; Huber \& Watson, 2013; Lee \& Han, 2008; Lee \& Mirchandani, 2010) (Medlin, Schneberger, \& Hunsinger, 2007; Noll \& Wikins, 2002; Stevens, Totaro, \& Zhu, 2011; Trauth, Farwell, \& Lee, 1993). Because the IT field keeps evolving with new technology, programmer/analyst ads often feature terms like "flexible" and "adaptive" (Lee \& Han, 2008). The authors recommended that future IS curriculum should include the following skills: general problem solving, quantitative, creative/innovative, adaptive/flexible, and knowledge of technological trends (Lee \& Han, 2008). Because personal traits enable individuals to learn skills more quickly in new areas, personal traits are the most important skills (Stevens, Totaro, \& Zhu, 2011).

\section{Job training versus career education}

IS faculties face the dilemma of balancing between emphasizing the fundamentals of IS and teaching upto-date new technology. Companies and students tend to have the short-term perspective (training to get the first job), while IS faculties take the long-term perspective (focusing on preparing students for a career) (Lightfoot, 1999). Companies need to understand that academic programs are not job training but career education (Downey, McMurtrey, \& Zeltmann, 2008; Trauth, Farwell, \& Lee, 1993). By balancing technical and soft skills, students may get their first jobs and launch a successful IT career (Huber \& Watson, 2013).

\section{Skills-curriculum gap}

\section{Gaps between required skills and school preparation}

According to several previous studies, IS program is deficient. IS students lack the critical skills desired from the employers' perspective (Aken \& Michalisin, 2007; Lee \& Han, 2008). In an early study, the expectation gap between company needs and academic preparation was empirically examined by surveying practitioners and IS professors (Trauth, Farwell, \& Lee, 1993). An empirical study compared IS students' perceptions of the IT technical skills demanded by industry and the IT technical skills sought in online job advertisements (Medlin, Schneberger, \& Hunsinger, 2007). They found several gaps between students' perceptions and the actual IT skills companies look for (Medlin, Schneberger, \& Hunsinger, 2007). This research suggests that students do not have a clear insight into marketplace skill demands and need career guidance. Another empirical research examined if the importance of several skills for entry-level IT employees are perceived differently by industry practitioners and academic faculty (Aasheim, Li, \& Williams, 2009). The survey results showed no significant difference between IT managers' and faculty's perceptions of the average importance of broader skill categories.

\section{Job skills needed and IS curriculum}

IS educators face the constant challenges of keeping the IS curriculum up to date due to emerging new technological changes and the industry demand to provide graduates with relevant skills (Janicki, Cummings, \& Kline, 2014). In an employer survey of IS/IT professionals that drills down to identify the 


\section{Issues in Information Systems}

Volume 22, Issue 3, pp. 39-51, 2021

detailed job skills, the authors found that compared to previous survey results of 2008, the new results highlight the growing demands for Big Data and its many components as well as project management skills (Janicki, Cummings, \& Kline, 2014). An empirical study of IS graduates found that about one-third of them worked as technical support (Legier, Woodward, \& Martin, 2013). It also discovered that the top four tasks conducted by the most significant number of IS graduates are providing end-user support, installing software, managing information, and installing and maintaining computer devices/components (Legier, Woodward, \& Martin, 2013). Most IS graduates perceived that they were well prepared for the IS jobs based on their coursework (Legier, Woodward, \& Martin, 2013).

\section{IT specializations}

\section{Diverse IT job positions}

An early study identified distinct IT career paths, spanning the spectrum of technical orientation at one end and business and functional orientation at the opposite end (Trauth, Farwell, \& Lee, 1993). A continuous trend is that IS jobs become more diversified than before, and a single general IS curriculum cannot prepare students for all IS positions (Lee, Trauth, \& Farwell, 1995). Besides commonly stereotyped IT positions, computer technician and programmer, there are a large variety of IS-related job positions: business analyst, system analyst, quality assurance tester, technical writer, user support representative, network administrator, database administrator, project manager, consultant, and salesperson (Kroenke, 2014).

\section{Career tracks in IS curriculum}

While IS specialization is vital in the real world, corresponding career tracks are less examined in the literature of IS curriculum (Hwang \& Curl, 2014; Hwang \& Soe, 2010). One empirical study found that among the 450 business schools in the United States, 110 bachelor IS programs offered a total of 304 career tracks, which are classified into 11 categories: IS Disciplines (CIS/CS/IT/MIS), Web Technologies/Ecommerce, Applications Development, Networking/Telecommunications, Information Assurance, Business Functional Applications, Information Management, Specialized Information Systems/Studies, Systems/Business Analysis, End User Support/Training, and Decision Support (Hwang \& Soe, 2010). Another more recent study discovered that among 401 IS undergraduate programs in the United States, 82 programs offered 241 career tracks (Hwang \& Curl, 2014).

\section{Prepare students for a specific career}

IS educators are facing two practical challenges: 1) how to prepare business students in the era of big data? 2) how do we increase enrollment in IS courses in business programs? (Wang \& Wang, 2016). The researchers redesigned the Database course to address both these challenges, and the new course is attractive to all business majors (Wang \& Wang, 2016). In an empirical research, requested skills for Network Engineers were collected, categorized, summarized, and discussed (Morris, Fustos, \& Haga, 2012). These results help modify network/telecommunication courses/curriculum to better prepare students for working as Network Engineers (Morris, Fustos, \& Haga, 2012). For example, they found that Linux, Unix, and Cisco's IOS show up very strong as requested skills for Network Engineer. IS faculty may consider covering such contents in the curriculum (Morris, Fustos, \& Haga, 2012). 


\section{Issues in Information Systems}

Volume 22, Issue 3, pp. 39-51, 2021

\section{Various skills}

\section{Technical skills in demand}

With an empirical content analysis of online job advertisements, Windows, Java, SQL Server, and .NET were identified as the most demanded skills for software developers (Ven \& Chuang, 2008). A data mining program for web content was employed to obtain a quarter-million U.S. job advertisements for IT graduates from various job websites and extract skills mentioned in those job ads (Litecky, Aken, Prabhakar, \& Arnett, 2009). The top three general technical skills are system integration, security, and testing. The top three programming languages are HTML, SQL, and Java (Litecky, Aken, Prabhakar, \& Arnett, 2009). The dynamics of the importance of IS/IT skills were studied from the viewpoint of IT managers using latent growth curve modeling (Lee \& Mirchandani, 2010). This empirical research found that in the future, the five most essential skills are IS security, data management, project management, business skills, Web applications, and wireless communications and applications (Lee \& Mirchandani, 2010).

\section{A wide range of IT skills}

Except for computer technicians and perhaps quality assurance testers, all IT positions demand an undergraduate degree, business knowledge, and good writing and verbal communication skills (Kroenke, 2014). A good network administrator/manager needs to have the following skills: computer skills, people skills, management skills, financial planning skills, knowledge of statistics, and speaking and writing skills (White, 2012). A system analyst can play three distinct roles in an organization: as a consultant, as a supporting expert, and as an agent of change (Kendall \& Kendall, 2014). Therefore, system analysts need to possess a wide range of skills. A system analyst should be a good problem solver, willing to undertake a challenge and figure out a solution. A system analyst should also have good communication skills and interpersonal skills to do well at this job. A system analyst should be able to relate meaningfully to both business users and team members in the process of developing the new information system (Kendall \& Kendall, 2014).

A software developer's competency can be classified into knowledge, skill, and ability (Ven \& Chuang, 2008). Knowledge related to software development includes object-oriented concepts, relational database concepts, data structures, and software development life cycles. Hard or technical skills include Java, Visual Basic, SQL Server, and Windows. Soft skills or abilities include information gathering, reading, writing, speaking, and listening (Ven \& Chuang, 2008).

Another empirical work concentrated on investigating the expected knowledge and skills for IS professionals in three groups: end-user support, programmers, and analysts (Noll \& Wikins, 2002). Their survey results showed that "soft skills," such as communication, project management, and collaboration, and teamwork, become increasingly critical to all areas of IS professionals (Noll \& Wikins, 2002). Therefore, writing, presentation, group work, and developing interpersonal relationships should be incorporated into IS curriculum (Noll \& Wikins, 2002). Soft skills are non-technical and include personality traits, problem-solving skills, interpersonal skills, and work ethic (Aken \& Michalisin, 2007). On the other hand, hard skills include technology-based and non-technology-based, such as general business skills (Aken \& Michalisin, 2007). Existing studies establish that companies emphasize more on soft skills than hard skills (Aken \& Michalisin, 2007).

Another study empirically analyzed the skills required for entry-level programmer/analysts in Fortune 500 companies (Lee \& Han, 2008). By analyzing job advertisements posted on Fortune 500 company websites, the authors found that programmer/analysts in Fortune 500 companies carried out various roles from 


\section{Issues in Information Systems}

Volume 22, Issue 3, pp. 39-51, 2021

computer code writer, technical experts to business personnel (Lee \& Han, 2008). Prior empirical studies indicated that behavioral skills, such as business knowledge and communication, became increasingly important for programmers (Lee \& Han, 2008). Since less than $5 \%$ of job ads from the Fortune 500 mentioned certifications, it seemed that we could not conclude that certifications are essential to job applicants (Lee \& Han, 2008).

Another empirical research identified the crucial skills required of new IS graduates from the view of employers and then mapped the skills into a comprehensive IS curriculum (Downey, McMurtrey, \& Zeltmann, 2008). The survey results demonstrated that technical skills (particularly SQL, at least two programming languages, and web design proficiency) are critical. At the same time, the fundamental concepts and knowledge in both business and IT are also important (Downey, McMurtrey, \& Zeltmann, 2008). The authors found that personal attributes, such as problem-solving, critical and creative thinking, written and oral communications, and team skills, are still most important (Downey, McMurtrey, \& Zeltmann, 2008). However, specific software packages, such as ERP, can be learned on the job (Downey, McMurtrey, \& Zeltmann, 2008).

Another empirical study evaluated the skill and knowledge required of entry-level IT employees based on a survey of practitioners (Aasheim, Williams, \& Butler, 2009). This research discovered that interpersonal and personal skills are ranked highest, closely followed by technical skills. Organizational knowledge, knowledge of primary business function, in particular, is also rated critical, but less than technical skills (Aasheim, Williams, \& Butler, 2009).

Both practitioners and faculty ranked the importance of skill categories in this descending order: interpersonal traits/skills, personal traits/skills, technical skills, organizational skills, and work experience/GPA (Aasheim, Li, \& Williams, 2009).

For IT departments in non-IT firms, technical skills are essential, and non-technical skills are also essential (Gallagher, Kaiser, Simon, Beath, \& Goles, 2010). Furthermore, the skills most sought in new mid-level hires and most critical to preserve in-house are non-technical skills such as business domain knowledge, relationship skills, and project management (Gallagher, Kaiser, Simon, Beath, \& Goles, 2010). These nontechnical skills are essential because they facilitate the IT department to collaborate well with other departments, internal users, suppliers, and external customers (Gallagher, Kaiser, Simon, Beath, \& Goles, 2010).

Many students have a misconception that IS career as heads-down programmer with activities routinely outsourced. On the contrary, IS professional requires a rich mix of technical skills, creativity, organizational understanding, and entrepreneurship (Davis, Gray, Madnick, Nunamaker, Sprague, \& Whinston, 2010). Unlike super-techie, IS major students should have a delicate balance of technical skills, business skills, and people skills. Employers should understand that they hire some IS students at entry-level for their management potential (Davis, Gray, Madnick, Nunamaker, Sprague, \& Whinston, 2010). Having a solid understanding of how to use technology to improve the performance of companies, IS students with a substantial business degree are potential managers. They may have a career in management (Davis, Gray, Madnick, Nunamaker, Sprague, \& Whinston, 2010).

Another empirical research showed that to become a relevant and competent IT professional, an individual should begin with fundamental skills such as interaction-oriented personal traits and communication skills, then acquire advanced skills in project management, collaboration, and IT facilitation and promotion (Eom \& Lim, 2012). The authors suggest that the right balance should be maintained between traditional technology skills and non-IT skills in IT education (Eom \& Lim, 2012). 


\section{Issues in Information Systems}

Volume 22, Issue 3, pp. 39-51, 2021

By applying nominal grouping with the MIS advisory board to determine critical skills that IS students need, the researchers also found that people skills are as necessary as technical skills (Huber \& Watson, 2013). The board members assumed IS students already have good foundational IT skills, and their advice concentrated on soft skills, such as networking and maintaining a relationship (Huber \& Watson, 2013).

\section{Comparing different types of skills}

An empirical study significantly expanded the number of organizations from which IT professionals evaluate critical skills by including many small firms (Stevens, Totaro, \& Zhu, 2011). While computer languages are viewed not as important (only SQL is ranked in the top 25 skills), core knowledge is regarded as a higher value (Stevens, Totaro, \& Zhu, 2011). Moreover, IT professionals consider ethics and security very important, perhaps due to the financial and legal concerns of security breaches (Stevens, Totaro, \& Zhu, 2011).

According to the Society for Information Management (SIM) survey, the top 15 skills that SIM's members looked for in entry-level IT employees are 1. Ethics and morals, 2. Critical thinking, 3. Collaboration, 4. Problem-solving, 5. Oral communication, 6. Written communication, 7. User relationship management, 8. Creativity/innovation, 9. Managing expectations, 10. Programming/application development, 11. Decision making, 12. Functional area knowledge, 13. Project leadership, 14. Database, 15, System analysis (Lundquist, 2008). Since IS security is the No. 1 concern in the corporate technology world and employees are the top sources of security breaches, it is not surprising that ethics and morals are placed at the top of the critical skills list (Lundquist, 2008). Technical skills such as programming, database, and system analysis being ranked at the bottom of the list are consistent with other studies (Aasheim, Li, \& Williams, 2009; Aasheim, Williams, \& Butler, 2009).

\section{Integrating soft skills for IT jobs}

A conceptual model was created and used as a common framework to provide IS students a holistic understanding of the IS field and cultivate an overall feeling of connectedness across seemingly disjointed IS classes (May \& Lending, 2015). The evidence shows that the integrated IS curriculum model has an initial success at the researchers' university (May \& Lending, 2015). Suppose IS graduates have competencies in technical skills and soft skills, such as interpersonal communication, teamwork, time management, planning, and organizational skills. In that case, IS graduates will be more marketable in the workforce (Woodward, Sendall, \& Ceccucci, 2010). Team and project-based learning methods have been applied to incorporate soft skills with technical skills. This integrated approach helps students obtain a deeper understanding and appreciation of the significance of soft skills (Woodward, Sendall, \& Ceccucci, 2010). The lack of mutual understanding between IS students and professionals and their businesses counterpart causes a collapse in communication and interaction and a management contention (Hall, 2011). Teaching cultural literacy to both IS and business students and preparing them to be immersed socially in technical business environments will address social collapse (Hall, 2011).

\section{Job offer and employer characteristics}

\section{Factors affecting job offer}

An empirical research examined the essential factors that help IS students secure full-time job offers (Fang, Lee, Lee, \& Huang, 2004). By surveying IS major senior students, they found that good academic performance (GPA 3.5 or above), networking (telecommunication) related internship and double majors 


\section{Issues in Information Systems}

Volume 22, Issue 3, pp. 39-51, 2021

are critical factors for securing employment (Fang, Lee, Lee, \& Huang, 2004). However, another empirical study revealed that having a high GPA is less valuable than possessing relevant work experience for IS students looking for entry-level jobs (Aasheim, Williams, \& Butler, 2009).

\section{Employer's IT orientation}

Non-IT firms refer to those whose primary business is not producing, servicing, and selling IT-related products and services (Gallagher, Kaiser, Simon, Beath, \& Goles, 2010; Goles, Hawk, \& Kaiser, 2008). About $79 \%$ of IT workers are employed in IT departments of non-IT firms in 2004 (Gallagher, Kaiser, Simon, Beath, \& Goles, 2010).

In an empirical study on skills sought by IT services and software providers, the authors found that IT firms emphasize more on business domain and project management skills than on technical skills (Goles, Hawk, $\&$ Kaiser, 2008). IT provider firms have become more interested in higher-level IT work such as systems integration than traditional commodity work such as programming (Goles, Hawk, \& Kaiser, 2008). Business domain, project management, and sourcing capabilities are all ranked as more important than technical skills for IT provider firms. Technical skills are regarded as necessary to achieve IT firms' mission, but not sufficient in the sense that technical skills alone cannot lead to a competitive advantage (Goles, Hawk, \& Kaiser, 2008). While the types of skills non-IT firms seek for entry-level IT employees are mainly technical, the types of skills desired by IT firms for entry-level IT employees are more diverse (Goles, Hawk, \& Kaiser, 2008). One potential explanation is that IT provider firms value customer-centric and client-facing skills and expect their entry-level employees to be capable of working well with clients from day one (Goles, Hawk, \& Kaiser, 2008). Extant research suggested that non-technical skills are more important than technical skills to internal IT departments in non-IT firms. Just because parts of the functions of IT departments are outsourced to IT provider firms, it does not mean that the value of those non-technical skills is diminished (Goles, Hawk, \& Kaiser, 2008). Therefore, individuals should possess technical expertise and business-related and soft skills to become well-rounded and qualified IT professionals (Goles, Hawk, \& Kaiser, 2008).

Based on IT job seekers' images of firms, IT employers are classified into three groups: IT vendors, IT consulting firms, and non-IT-oriented firms that hire in-house IT workers (Thatcher, Dinger, \& George, 2012). An empirical research demonstrated that entry-level job seekers could be segmented into distinct groups according to their images of firms. Each group has unique preferences for a firm and job characteristics (Thatcher, Dinger, \& George, 2012). First, entry-level IT job seekers preferring in-house IT departments value the nature of the IT works less than those entry-level IT job seekers preferring IToriented firms. Second, entry-level IT job seekers preferring in-house IT departments value prestige less than those entry-level IT job seekers preferring IT-oriented firms. Third, entry-level IT job seekers preferring in-house IT departments value job security more than those entry-level IT job seekers preferring IT consulting firms (Thatcher, Dinger, \& George, 2012). Seven IT job seeker characteristics relevant for firm preferences are identified: teamwork skills, IT skills, interpersonal skills, work ethic, creativity and achievement, degree, and leadership skills (Thatcher, Dinger, \& George, 2012). Empirical results show no significant differences in firm preferences of job seeker characteristics across the three groups (IT vendors, IT consulting firms, and non-IT-oriented firms) (Thatcher, Dinger, \& George, 2012). Therefore, in the entry-level IT labor market, although job seekers have different perceptions of employers' IT orientation and value IT jobs in different ways, all three types of firms prefer the same types of new hires' characteristics (Thatcher, Dinger, \& George, 2012). Moreover, for all three types of employers, the highest valued skills are interpersonal skills, followed by the work ethic and IT skills (Thatcher, Dinger, \& George, 2012). 


\section{Issues in Information Systems}

Volume 22, Issue 3, pp. 39-51, 2021

\section{Employer's size and prestige}

In general, IS workers prefer to be employed at large and prestigious firms because of their technical competence and identity (Lee \& Han, 2008). Large companies view globalization issues as more critical knowledge or skill area than small companies (Stevens, Totaro, \& Zhu, 2011). Nevertheless, in large companies, many employees work in "siloed" areas. However, smaller and more innovative companies do not have as many "siloed" constraints as in some large companies. Therefore, the perceived "prestige" of working at larger companies is fading away under such circumstances.

\section{Challenge of work-life-education balance for students}

A survey of IS students discovered that over three-quarters of the students work during their 4-year degree. Many students, especially non-traditional students, face the immense challenge of work-life-education balance (Legier Jr. \& Soares, 2014). The researchers suggest schools provide a more inclusive learning environment and use podcasts and virtual labs through cloud computing to serve non-traditional students better. Moreover, the authors recommend that schools assist students in finding IT-related jobs, which will enrich their learning IT skills beyond classroom learning (Legier Jr. \& Soares, 2014).

\section{Summary}

While the IS curriculum may stay relatively stable, the IT industry is changing rapidly with various innovations in recent years. The emerging technologies include data mining, machine learning, parallel processing, AI, IoT, big data analytics, cloud-based platforms such as AWS, and digitalization due to the Covid-19 pandemic. Consequently, the industry demands in skills and labor forces also evolve accordingly over the years.

IS educators have the privilege and duty to prepare our IS students for entry-level IT jobs and long-term professional careers. Understanding skills and qualifications demanded by the industry is crucial for improving and redesigning the IS curriculum to better students' chances of launching into their initial career. This research examines many articles in the literature on the topic of the skills needed for entry-level IT positions, and related IS curriculum issues. We identify essential themes and categorize them into the following broad areas. 1) Historical and big-picture overview: Historical perspective of IS job market and IS curriculum, Career paths of IS graduates, Evolving nature of IT, and Job training versus career education. 2) Skills-curriculum gap: Gaps between required skills and school preparation, Job skills needed, and IS curriculum. 3) IT specializations: Diverse IT job positions, Career tracks in IS curriculum, and Prepare students for a specific career. 4) Various skills: Technical skills in demand, A wide range of IT skills, Comparing different types of skills, and Integrating soft skills for IT jobs. 5) Job offer and employer characteristics: Factors affecting job offer, Employer's IT orientation, and Employer's size and prestige. 6) Challenge of work-life-education balance for students.

This study makes the following potential contributions. First, it summarizes the essential aspects of extant research on this salient topic and can serve as a starting point for IS researchers interested in this area. Second, this paper can benefit IS faculty by providing relevant information to improve and redesign the IS curriculum. Third, this research also helps IS students by informing them of the broad breadth of the IT field, historical trends, and current skills demanded by the industry. Fourth, this study may also benefit the industry and employers in the long run. Inspired by this study, IS faculty could adjust the IS curriculum to be more updated and relevant. Hence, IS students would be better prepared to meet industry demand. Therefore, employers will have more qualified job candidates in the pipeline. 


\section{Issues in Information Systems}

Volume 22, Issue 3, pp. 39-51, 2021

We acknowledge that the literature discussed in this paper is not exclusive. There might be other relevant researches not covered by this study. Next, we plan to update the literature review to incorporate new research in the past five years. Most of the literature was years old, but due to technological breakthroughs, the industry demands and skill requirements have changed significantly. Thus, a review relying on only past literature may not be sufficient to provide the most updated insights. In the next stage of our research project, we plan to combine the literature-based findings with empirical analyses of current IT job postings. This hybrid approach would provide a more comprehensive, solid, and timely insight on the topic. This research is a part of our ongoing project. We plan to extend this study by conducting a series of empirical case studies to enrich our understanding of this crucial and evolving topic. The empirical results from the next stage of this project will be reported in another paper soon.

\section{References}

Aasheim, C. L., Li, L., \& Williams, S. (2009, Fall). Knowledge and skill requirements for entry-level information technology workers: A comparison of industry and academia. Journal of Information Systems Education, 20(3), 349-356.

Aasheim, C. L., Williams, S., \& Butler, E. S. (2009). Knowledge and skill requirements for IT graduates. Journal of Computer Information Systems, 49(3), 48-53.

Aken, A., \& Michalisin, M. D. (2007). The impact of the skills gap on the recruitment of MIS graduates. The Proceedings of SIGMIS-CPR (pp. 105-111). St. Louis: ACM.

Bernstein, C. (2013, February 28). IT skills shortage: The other critical cliff facing enterprises. EWeek. Retrieved December 18, 2014, from http://www.eweek.com/print/it-management/it-skillsshortage-the-other-critical-cliff-facing-enterprises

Bluestein, G., \& Davis, J. (2014, December 10). Report: Georgia's employers can't find qualified workers in key fields. The Atlanta Journal-Constitution. Retrieved December 22, 2014, from http://www.myajc.com/news/news/state-regional-govt-politics/report-georgias-employers-cantfind-qualifiedwork/njQDf/?ecmp=ajc_social_facebook_2014_politics_sfp\#f3741de4.257099.735578

Craver, M., \& DeSenne, M. (2011, September 1). 10 of today's hottest jobs. Retrieved December 22, 2014, from Yahoo Finance: http://finance.yahoo.com/blogs/power-your-future/10-today-hottestjobs-184644468.html

Davis, G. B., Gray, P., Madnick, S., Nunamaker, J. F., Sprague, R., \& Whinston, A. (2010, December). Ideas for the future of the IS field. ACM Transactions on Management Information Systems, 1(1), 2:1-2:15. doi:10.1145/1877725.1877727

Downey, J. P., McMurtrey, M. E., \& Zeltmann, S. M. (2008, Fall). Mapping the MIS curriculum based on critical skills of new graduates: An emprical examination of IT professionals. Journal of Information Systems Education, 19(3), 351-363.

Eom, M. T., \& Lim, C. (2012). Critical skills to be competent and relevant IT personnel: Do today's IT personnel possess requisite skills? Journal of Information Technology Management, XXIII(4), 3349. 


\section{Issues in Information Systems}

Volume 22, Issue 3, pp. 39-51, 2021

Fang, X., Lee, S., Lee, T. E., \& Huang, W. (2004, Summer). Critical factors affecting job offers for new MIS graduates. Journal of Information Systems Education, 15(2), 189-203.

Gallagher, K. P., Kaiser, K. M., Simon, J. C., Beath, C. M., \& Goles, T. (2010, June). The requisite variety of skills for IT professionals. Communications of the ACM, 53(6), 144-148. doi:10.1145/1743546.1743584

Goles, T., Hawk, S., \& Kaiser, K. M. (2008, April). Information technology workforce skills: The software and IT services provider perspective. (R. Hirschheim, J. Dibbern , \& A. Heinzl, Eds.) Information Systems Frontiers, 10(2), 179-194. doi:10.1007/s10796-008-9072-9

Hall, B. (2011, June). IS/IT Education vs. Business Education: The Plight of Social Collapse in Technical Business Environments. Information Systems Education Journal, 9(2), 55-64.

Harris, A. H., Greer, T. H., Morris, S. A., \& Clark, J. W. (2012, Fall). Information Systems Job Market Late 1970's-Early 2010's. Journal of Computer Information Systems, 53(1), 72-79.

Huber, M., \& Watson, H. J. (2013, April). Wisdom of the sages: Preparing students for career skills. Communications of the Association for Information Systems, 32(1), 95-106. Retrieved from http://aisel.aisnet.org/cais/vol32/iss1/3

Hwang, D., \& Curl, S. S. (2014, May). The Market for Career Tracks in Undergraduate IS Curricula in the U.S. Information Systems Education Journal, 12(3), 4-17.

Hwang, D., \& Soe, L. L. (2010, April 21). An Analysis of Career Tracks in the Design of IS Curricula in the U.S. Information Systems Education Journal, 8(13), 3-17. Retrieved from http://isedj.org/8/13/

Janicki, T. N., Cummings, J., \& Kline, D. (2014, November). Information Technology Job Skill Needs and Implications for Information Technology Course Content. Information Systems Education Journal, 12(6), 59-70.

Joseph, D., Boh, W. F., Ang, S., \& Slaughter, S. A. (2012, June). The career paths less (or more) traveled: A sequence analysis of IT career histories, mobility patterns, and career success. MIS Quarterly, $36(2), 427-452$.

Kendall, K. E., \& Kendall, J. E. (2014). Systems Analysis and Design (9th ed.). Upper Saddle River, New Jersey, U.S.A.: Pearson.

Kroenke, D. (2014). Experiencing MIS (4th ed.). Upper Saddle River, New Jersey, U.S.A.: Prentice Hall.

Lee, C. K., \& Han, H.-J. (2008, Spring). Analysis of skills requirement for entry-level programmer/analysts in Fortune 500 corporations. Journal of Information Systems Education, 19(1), 17-27.

Lee, D., Trauth, E., \& Farwell, D. (1995, September). Critical skills and knowledge requirements of IS professionals: A joint academic/industry investigation. MIS Quarterly, 19(3), 313-340. 


\section{Issues in Information Systems}

Volume 22, Issue 3, pp. 39-51, 2021

Lee, K., \& Mirchandani, D. (2010, Summer). Dynamics of the importance of IS/IT skills. Journal of Computer Information Systems, 50(4), 67-78.

Legier Jr., J. T., \& Soares, A. (2014, November). IT educational experience and workforce development for Information Systems and Technology students. Information Systems Education Journal, 12(6), 71-82.

Legier, J., Woodward, B., \& Martin, N. (2013, June). Reassessing the Skills Required of Graduates of an Information Systems Program: An Updated Analysis. Information Systems Education Journal, 11(3), 79-89.

Lightfoot, J. M. (1999, September/October). Fads versus fundamentals: The dilemma for information systems curriculum design. Journal of Education for Business, 75(1), 43-50.

Litecky, C., Aken, A., Prabhakar, B., \& Arnett, K. (2009). Skills in the MIS job market. The Proceedings of the Fifteenth Americas Conference on Information Systems (pp. 1-7). San Francisco, California: Association for Information Systems. Retrieved from http://aisel.aisnet.org/amcis2009/255

Longenecker, H. E., Feinstein, D., \& Clark, J. D. (2013, December). Information Systems Curricula: A Fifty Year Journey. Information Systems Education Journal, 11(6), 71-95.

Lundquist, E. (2008, December 1). The skills that really matter. EWeek, p. 46.

May, J., \& Lending, D. (2015, Summer). A Conceptual Model for Communicating an Integrated Information Systems Curriculum. Journal of Computer Information Systems, 55(4), 20-27.

Medlin, B. D., Schneberger, S., \& Hunsinger, D. S. (2007). Perceived technical information technology skill demands versus advertised skill demands: An empirical study. Journal of Information Technology Management, XVIII(3-4), 14-23.

Morris, G., Fustos, J., \& Haga, W. (2012, February). Preparing for a Career as a Network Engineer. Information Systems Education Journal, 10(1), 13-20.

Noll, C. L., \& Wikins, M. (2002). Critical skills of IS professionals: A model for curriculum development. (G. Lowry, Ed.) Journal of Information Technology Education, 1(3), 143-154.

Stevens, D., Totaro, M., \& Zhu, Z. (2011, Spring). Assessing IT critical skills and revising the MIS curriculum. Journal of Computer Information Systems, 51(3), 85-95.

Thatcher, J., Dinger, M., \& George, J. F. (2012, July). Information technology worker recruitment: An empirical examination of entry-level IT job seekers' labor market. Communications of the Association for Information Systems, 31(1), 1-34. Retrieved from http://aisel.aisnet.org/cais/vol31/iss1/1

Trauth, E. M., Farwell, D. W., \& Lee, D. (1993, September). The IS expectation gap: Industry expectations versus academic preparation. MIS Quarterly, 17(3), 293-307. 


\section{Issues in Information Systems}

Volume 22, Issue 3, pp. 39-51, 2021

Ven, J.-H., \& Chuang, C.-P. (2008, March). Skill requirements for software developers: Comparisons between U.S. and Taiwan. Journal of American Academy of Business, 12(2), 158-166.

Wang, S., \& Wang, H. (2016, Spring). Renewal of Classics: Database Technology for All Business Majors. Journal of Computer Information Systems, 56(3), 211-217.

White, C. (2012). Data Communications and Computer Networks: A Business User's Approach (7th ed.). Course Technology.

Woodward, B. S., Sendall, P., \& Ceccucci, W. (2010, March 2). Integrating Soft Skill Competencies Through Project-based Learning Across the Information Systems Curriculum. Information Systems Education Journal, 8(8), 3-15. Retrieved from http://isedj.org/8/8/ 